\title{
Penerapan Pembelajaran TGT (Team Games Tournament) pada Materi Sistem Gerak pada Manusia untuk Meningkatkan Motivasi dan Hasil Belajar Siswa
}

\author{
Kurniasih Dwi Wilandari \\ SMP Negeri 1 Nusawungu, Cilacap \\ Rawabangus, Danasri, Nusawungu, Rawabangus, Danasri, Nusawungu, \\ Kabupaten Cilacap, Jawa Tengah \\ Email: bdmartono7@gmail.com
}

\begin{abstract}
Abstrak
Penelitian ini merupakan jenis Penelitian Tindakan Kelas (PTK) yang merupakan suatu penelitian yang dilakukan secara sistematis reflektif terhadap tindakan yang dilakukan oleh guru sebagai peneliti, mulai dari perencanaan, pelaksanaan, sampai dengan penilaian untuk mempebaiki kondisi pembelajaran. Dalam penelitian tindakan kelas ini peneliti menggunakan dua siklus, yang masing-masing siklusnya terdiri dari empat tahap yaitu rencana (planning), tindakan (action), observasi (observation), dan refleksi (reflection). Instrumen penelitian berupa tes yang bertujuan untuk mengetahui hasil belajar siswa dan non tes yang berupa lembar observasi yang diisi oleh kolaborator, dan lembar angket motivasi siswa yang diisi oleh siswa. Subjek penelitian ini adalah siswa kelas VIII G SMP Negeri 1 Nusawungu yang berjumlah 30 siswa. Teknik analisis data yang digunakan untuk proses penilaian adalah deskriptif kuantitatif untuk mengetahui peningkatan hasil belajar siswa, dan deskripsi kualitatif untuk mengetahui motivasi belajar siswa.

Hasil penelitian tindakan kelas ini berupa penerapan model pembelajaran TGT (Team Games Tournament) yang memberikan peningkatan terhadap motivasi dan hasil belajar siswa dari pra siklus, siklus I, siklus II secara berurutan yaitu memliki persentase kelulusan sebesar 33,33\%; 43,33\%; dan 83,33\%, sedangkan motivasi siswa dari kategori cukup menjadi kategori baik. sehingga dapat disimpulkan bahwa penerapan model pembelajaran tipe TGT dapat meningkatkan motivasi dan hasil belajar siswa.
\end{abstract}

Kata Kunci : model pembelajaran TGT, motivasi siswa, hasil belajar siswa.

\begin{abstract}
This research is a type of Classroom Action Research (CAR) which is a research conducted systematically reflective of the actions taken by the teacher as a researcher, ranging from planning, implementing, to assessments to improve learning conditions. In this class action research researchers used two cycles, each of which consisted of four stages: planning, action, observation, and reflection. The research instrument was in the form of a test aimed at finding out student learning outcomes and non-tests in the form of an observation sheet filled out by collaborators, and a student motivation questionnaire sheet filled out by students. The subjects of this study were students of class VIII G of SMP Negeri 1 Nusawungu, totaling 30 students. The data analysis technique used for the assessment process is quantitative descriptive to find out the improvement of student learning outcomes, and qualitative descriptions to determine student motivation.

The results of this class action research are the application of the TGT learning model (Team Games Tournament) which provides an increase in student motivation and learning outcomes from pre-cycle, cycle I, cycle II in sequence which has a percentage of
\end{abstract}


graduation of $33.33 \%$; $43.33 \%$; and $83.33 \%$, while the motivation of students from the category is quite good. so it can be concluded that the application of the TGT type of learning model can increase motivation and student learning outcomes.

Keywords: TGT learning model, student motivation, student learning outcomes.

\section{PENDAHULUAN}

Dalam upaya meningkatkan mutu pendidikan, mutu guru merupakan salah satu komponen yang mempunyai peran sangat penting (Basuki Wibawa, 2003). Salah satu upaya untuk meningkatkan mutu pendidikan di sekolah adalah dengan cara perbaikan proses belajar mengajar atau pembelajaran. Berbagai konsep dan wawasan baru tentang pembelajaran di sekolah telah muncul dan berkembang seiring pesatnya ilmu pengetahuan dan teknologi. Guru sebagai pendidik yang menduduki posisi strategis dalam pengembangan sumber daya manusia, dituntut untuk terus mengikuti perkembangan konsep-konsep baru dalam dunia pendidikan (B. Suryosubroto, 2002). Tujuan pendidikan merupakan sesuatu yang ingin dicapai oleh kegiatan pendidikan. Pendidikan Nasional bertujuan untuk mengembangkan potensi siswa agar menjadi manusia yang beriman dan bertakwa kepada Tuhan Yang Maha Esa, berakhlak mulia, sehat, berilmu, cakap, kreatif, mandiri, dan menjadi warga negara yang demokratis serta bertanggung jawab (Wiji Suwarno, 2006). IPA adalah suatu bentuk metode yang berpangkal pada pembuktian hipotesa. Dalam Pusat Kurikulum (2006: 4), IPA berkaitan dengan cara mencari tahu tentang alam secara sistematis, sehingga IPA bukan hanya penguasaan kumpulan pengetahuan yang berupa fakta-fakta, konsep-konsep, atau prinsip-prinsip saja tetapi juga merupakan suatu proses penemuan. Jika dilihat dari karakteristiknya, IPA sebenarnya berpotensi untuk menjadi pelajaran yang menarik, menyenangkan dan terkadang menumbuhkan rasa keingintahuan siswa untuk mencoba sesuatu yang bersifat positif. Sistem gerak pada manusia adalah salah satu meteri pelajaran di kelas VIII yang berisi tentang materi yang sangat benyak meliputi jenis tulang, bentuk tulang, jumlah dan susunan tulang, sendi, otot, dan macam-macam gerak serta kelainan pada tulang. Materi yang sangat banyak ini terkadang membuat siswa jenuh karena terlalu lama membahas materi yang sama, sehingga motivasi siswa untuk mempelajari materi ini menjadi rendah karena banyaknya materi yang harus dipelajari dalam satu bab.

Fenomena di lapangan selama ini menunjukkan bahwa dalam proses pembelajaran masih banyak permasalahan di dalamnya. Dari hasil pengamatan proses pembelajaran yang dilakukan di kelas VIII G SMP Negeri 1 Nusawungu pada mata 
pelajaran IPA khususnya materi sistem gerak pada manusia, ketika pembelajaran dilakukan secara diskusi, tetapi sebagian besar siswa kurang berperan aktif dalam proses diskusi tersebut. Motivasi dan perhatian siswa terhadap jalannya diskusi kurang, hal ini ditunjukkan dengan sedikitnya siswa yang berpartisipasi pada saat diskusi berlangsung baik itu dalam bertanya, mengemukakan pendapat maupun menjawab pertanyaan. Siswa disibukkan dengan kegiatannya masing-masing dan hanya fokus pada materi atau kasus yang sedang dihadapinya. Hanya terdapat beberapa siswa yang aktif dalam proses tersebut. Siswa yang lain hanya terdiam dan tidak merespon proses diskusi yang sedang berlangsung. Masalah tersebut terjadi karena penggunaan model pembelajaran yang kurang bervariasi sehingga menimbulkan kejenuhan pada peserta didik yang dapat menyebabkan pembelajaran yang pasif. Selama ini model pembelajaran yang digunakan guru di SMP N 1 Nusawungu, sebenarnya sudah tidak menggunakan model konvensional, pembelajaran sudah menggunakan model diskusi yang melibatkan partisipasi siswa. Hanya saja penggunaan model tersebut belum cukup untuk meningkatkan perhatian dan motivasi belajar siswa di sekolah, padahal motivasi menurut Nasution (2005), diakui sebagai hal yang sangat penting bagi pembelajaran di sekolah. Berdasarkan permasalahan tersebut, perlu adanya solusi yang tepat untuk perbaikan dalam proses pembelajaran di kelas VIII G SMP Negeri 1 Nusawungu, yaitu perlunya meningkatkan mutu proses pembelajaran pada aspek kualitas dalam hal perubahan tindakan proses belajar mengajar. Berdasarkan alasan tersebut, maka dilakukan penelitian tindakan kelas guna memperbaiki proses pembelajaran.

Berdasarkan uraian latar belakang dan masalah-masalah yang dikemukakan di atas betapa pentingnya dilakukan peningkatan proses belajar dengan penerapan model pembelajaran yang tepat guna untuk meningkatkan motivasi belajar siswa. Model pembelajaran kooperatif tipe TGT (Team Games Tournament) diharapkan dapat meningkatkan motivasi dan hasil belajar siswa terhadap mata pelajaran IPA sehingga siswa tidak merasa jenuh dan bosan dalam mengikuti pelajaran di sekolah. Setelah guru melakukan refleksi diri, ditemukan beberapa masalah sebagai berikut :

1. Peserta didik pasif pada saat proses pembelajaran berlangsung

2. Adanya dominasi beberapa siswa pada proses pembelajaran

3. Model pembelajaran yang diterapkan kurang bervariasi

4. Sebagian besar siswa kurang termotivasi untuk belajar

Beberapa kajian teori yang relevan dalam penelitian ini antara lain: 


\section{Motivasi Belajar}

Istilah motivasi berasal dari kata motif yang dapat diartikan sebagai kekuatan yang terdapat dalam diri individu, yang menyebabkan individu tersebut bertindak atau berbuat. Motif tidak dapat diamati secara langsung, tetapi dapat diinterpretasikan dalam tingkah lakunya, berupa rangsangan, dorongan, atau pembangkit tenaga munculnya suatu tingkah laku tertentu. Dengan demikian, motivasi merupakan dorongan yang terdapat dalam diri seseorang untuk berusaha mengadakan perubahan tingkah laku yang lebih baik dalam memenuhi kebutuhannya (Hamzah B. Uno, 2008). Sedangkan Moh. Uzer Usman (2003), berpendapat bahwa motif merupakan daya atau kemauan dalam diri seseorang untuk melakukan sesuatu. Sedangkan motivasi adalah usaha membangkitkan motif-motif sehingga menjadi suatu perbuatan. Hakikat motivasi belajar adalah dorongan internal dan eksternal pada siswa-siswa yang sedang belajar untuk mengadakan perubahan tingkah laku, pada umumnya dengan beberapa indikator atau unsur yang mendukung. Hal tersebut mempunyai peranan besar dalam keberhasilan seseorang dalam belajar. Indikator motivasi belajar dapat diklasifikasikan sebagai berikut: 1) adanya hasrat dan keinginan berhasil; 2) adanya dorongan dan kebutuhan dalam belajar; 3) adanya harapan dan cita-cita masa depan; 4) adanya penghargaan dalam belajar; 5) adanya kegiatan yang menarik dalam belajar; 6) adanya lingkungan belajar yang kondusif, sehingga memungkinkan seorang siswa dapat belajar dengan baik (Hamzah B. Uno, 2008).

\section{Hasil Belajar}

Hasil belajar merupakan hasil yang dicapai seseorang setelah melakukan kegiatan belajar. Hasil belajar ini merupakan penilaian yang dicapai seorang siswa untuk mengetahui pemahaman tentang bahan pelajaran atau materi yang diajarkan sehingga dapat dipahami siswa. Untuk dapat menentukan tercapai atau tidaknya tujuan pembelajaran dilakukan usaha untuk menilai hasil belajar. Penilaian ini bertujuan untuk melihat kemajuan peserta didik dalam menguasai materi yang telah dipelajari dan ditetapkan (Suharsimi Arikunto, 2001). Hasil belajar tampak sebagai perubahan tingkah laku pada diri siswa, yang dapat diamati dan diukur dalam bentuk perubahan pengetahuan, sikap dan keterampilan (Oemar Hamalik, 2003). Berdasarkan uraian di atas, dapat disimpulkan bahwa hasil belajar merupakan hal penting dalam proses belajar mengajar, karena dapat menjadi petunjuk untuk mengetahui sejauh mana keberhasilan seorang siswa dalam kegiatan belajar mengajar yang telah dilaksanakan. Dengan demikian jika pencapaian hasil belajar itu tinggi, dapat dikatakan bahwa proses belajar mengajar itu berhasil. Menurut Bloom dalam Nana Sudjana (2006), ada tiga ranah 
(domain) hasil belajar, yaitu: 1). Ranah afektif, merupakan aspek yang berkaitan dengan perasaan, emosi, sikap, derajat penerimaan atau penolakan terhadap suatu objek; 2). Ranah psikomotor, merupakan aspek yang berkaitan dengan kemampuan melakukan pekerjaan yang melibatkan anggota badan, kemampuan yang berkaitan dengan gerak fisik; 3). Ranah kognitif, merupakan aspek yang berkaitan dengan kemampuan berpikir, kemampuan memperoleh pengetahuan, kemampuan yang berkaitan dengan perolehan pengetahuan, pengenalan, pemahaman, konseptualisasi, penentuan dan penalaran.

\section{Team Games Tournament}

Menurut (Slavin,2010:166-169), pembelajaran kooperatif tipe TGT terdiri dari lima komponen utama, yaitu : presentasi di kelas, tim (kelompok), game (permainan), turnamen (pertandingan), dan rekognisi tim (penghargaan kelompok). Prosedur pelaksanaan TGT mulai dari aktivitas guru dalam menyampaikan pelajaran, kemudian siswa bekerja dalam tim mereka untuk memastikan bahwa semua anggota tim telah menguasai pelajaran. Selanjutnya diadakan turnamen. Lebih lanjut, dijelaskan mengenai langkah- langkah pembelajaran TGT modifikasi dari Robert E. Slavin, yaitu sebagai berikut :

a. Presentasi Kelas. Pada awal pembelajaran, guru menyampaikan materi dalam penyajian kelas, biasanya dilakukan dengan pengajaran langsung atau dengan ceramah dan diskusi yang dipimpin oleh guru. Disamping itu, guru juga menyampaikan tujuan, tugas, atau kegiatan yang harus dilakukan siswa, dan memberikan motivasi. Pada saat penyajian kelas ini siswa harus benar-benar memperhatikan dan memahami materi yang disampaikan guru, karena akan membantu siswa bekerja lebih baik saat kerja kelompok dan pada saat game/turnamen karena skor game/ tournament akan menentukan skor kelompok

b. Belajar Kelompok (Tim). Guru membagi siswa dalam kelompok- kelompok kecil. Siswa bekerja dalam kelompok yang terdiri atas 5 orang yang anggotanya heterogen. Dengan adanya heterogenitas anggota kelompok, diharapkan dapat memotivasi siswa untuk saling membantu antar siswa yang berkemampuan lebih dengan siswa yang berkemampuan kurang dalam menguasai materi pelajaran. Hal ini akan menyebabkan tumbuhnya rasa kesadaran pada diri siswa bahwa belajar secara kooperatif sangat menyenangkan. Pada saat pembelajaran, fungsi kelompok adalah untuk lebih mendalami materi bersama teman kelompoknya dan lebih khusus untuk mempersiapkan anggota kelompok agar bekerja dengan baik dan optimal pada saat game/ turnament. Setelah guru menginformasikan materi dan tujuan pembelajaran, kelompok berdiskusi dengan menggunakan modul. Dalam kelompok terjadi diskusi 
untuk memecahkan masalah bersama, saling memberikan jawaban dan mengoreksi jika ada anggota kelompok yang salah dalam menjawab. Penataan ruang kelas diatur sedemikian rupa sehingga proses pembelajaran dapat berlangsung dengan baik.

c. Persiapan permainan/ pertandingan. Guru mempersiapkan pertanyaan- pertanyaan yang berhubungan dengan materi, bernomor 1 sampai 30. Kemudian guru mempersiapkan alat- alat untuk permainan, yaitu : kartu permainan yang dilengkapi nomor, skor, pertanyaan, dan jawaban mengenai materi.

d. Permainan/ Pertandingan (Game/Tournament). Permainan/ Pertandingan terdiri dari pertanyaan- pertanyaan yang dirancang untuk menguji pengetahuan yang diperoleh siswa dari penyajian kelas dan belajar kelompok. Tiap kelompok (tim) mendapat kesempatan untuk memilih kartu bernomor yang tersedia pada meja turnamen dan mencoba menjawab pertanyaan yang muncul. Apabila tiap anggota dalam suatu tim tidak bisa menjawab pertanyaannya, maka pertanyaan tersebut dilempar kepada kelompok lain, searah jarum jam. Tim yang bisa menjawab dengan benar pertanyaan itu, akan mendapat skor yang telah tertera dibalik kartu tersebut. Skor ini nantinya dikumpulkan tim untuk menentukan skor akhir tim. Pemilihan kartu bernomor akan digilir pada tiap-tiap tim secara bergantian searah jarum jam, sampai habis jatah nomornya.

e. Rekognisi Tim (Penghargaan Tim). Penghargaan diberikan kepada tim yang menang atau mendapat skor tertinggi, skor tersebut padaakhirnya akan dijadikan sebagai tambahan nilai tugas siswa. Selain itu diberikan pula hadiah (reward) sebagai motivasi belajar.

\section{METODE PENELITIAN}

Penelitian ini adalah penelitian tindakan kelas (PTK) yang bertujuan untuk meningkatkan motivasi belajar peserta didik. Penelitian ini diharapkan dapat memperbaiki proses pembelajaran guna meningkatkan kualitas pembelajaran. Penelitian tindakan kelas ini dilakukan secara kolaboratif, artinya penelitian ini tidak dilakukan sendiri tetapi bekerja sama dengan guru IPA kelas VIII G SMP Negeri 1 Nusawungu. Subyek dalam penelitian ini adalah peserta didik kelas VIII G SMP Negeri 1 Nusawungu yang berjumlah 30 siswa.

Penelitian yang dilaksanakan adalah Penelitian Tindakan Kelas (PTK) yaitu suatu cara yang dilakukan secara sistematis oleh guru dengan tujuan untuk pelaksanaan inovasi pendidikan dan peningkatan mutu pembelajaran. PTK adalah penelitian yang mengangkat $\underline{\text { masalah-masalalah yang aktual yang dilakukan oleh para guru yang merupakan }}$ 
pencermatan kegiatan belajar yang merupakan tindakan untuk memperbaiki dan meningkatkan praktik pembelajaran di kelas secara lebih profesional (Taniredja,et. al, 2010:15), dengan adanya Penelitian Tindakan Kelas ini diharapkan akan meningkatkan prestasi belajar siswa serta dapat mengatasi dan memcahkan masalah yang terdapat di dalam kelas selama proses pembelajaran. Dalam Penelitian Tindakan Kelas ini, peneliti menggunakan dua siklus. Tiap-tiap siklus terdiri dari empat tahap yaitu rencana (planning), tindakan (acting), observasi (observing),dan refleksi. Secara skematis siklus pembelajaran yang peneliti laksanakan dalam Penelitian Tindakan Kelas adalah sebagai berikut :

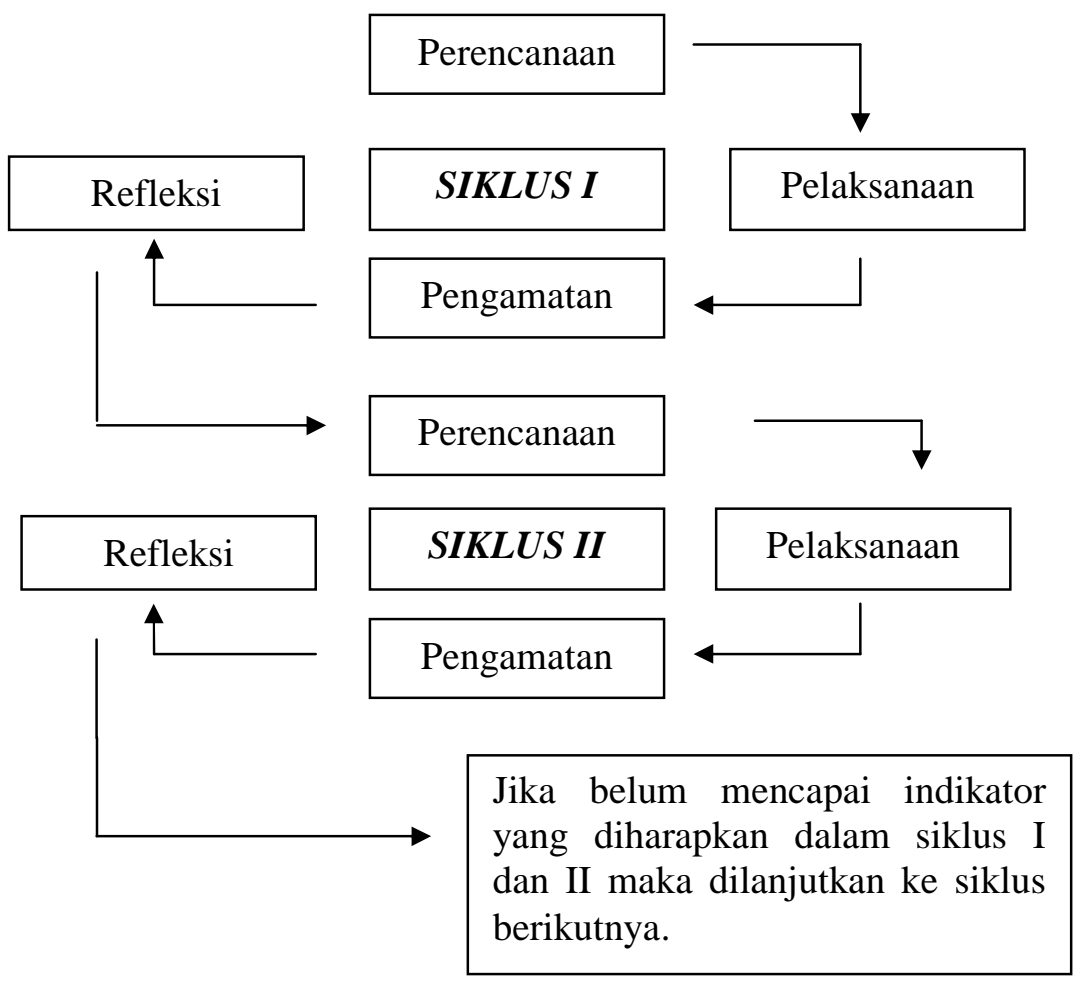

Gambar 1. Bagan model PTK

\section{HASIL DAN PEMBAHASAN}

Pelaksanaan PTK meliputi dua siklus yang masing-masing siklusnya terdiri dari empat fase yaitu perencanaan (planning), pelaksanaan (action), pengamatan (observation), dan refleksi (reflection). Hasil belajar kelas VIII G SMP Negeri 1 Nusawungu setelah menggunakan pembelajaran tipe TGT (Team Games Tournament) mengalami peningkatan persentese ketuntasan pada tiap siklusnya yaitu, pada kondisi awal persentase ketuntasan sebesar 33,33\% kemudian meningkat pada siklus I menjadi 43,33\% dan pada siklus II persentase ketuntasan menjadi $83,33 \%$. Selain dari hasil belajar juga dapat dilihat dari 
peningkatan skor yang didapatkan dari lembar observasi dan angket motivasi yang diberikan ke siswa.

Peningkatan aktivitas guru dalam melaksanakan pembelajaran di dalam kelas dengan menggunakan model TGT yang pada siklus I kegiatan pendahuluan mendapat skor 3,00 dengan kategori baik, kegiatan inti 2,5 dengan kategori baik, dan kegiatan penutup 2,75 dengan kategori baik, setelah dilakukan perbaikan pada siklus II mengalami peningkatan menjadi aktivitas pembelajaran yang dilakukan oleh guru pada kegiatan pendahuluan mendapat skor 3,67 termasuk kategori sangat baik, pada kegiatan inti mendapat skor 3,50 termasuk kategori sangat baik, dan pada kegiatan penutup mendapat skor 3,50 yang termasuk kategori sangat baik.

Motivasi belajar siswa mengalami peningkatan pada siklus I ke siklus II yaitu pada siklus I motivasi siswa mendapat skor rata-rata kelas sebesar 2,46 yang termasuk kategori cukup, dan pada siklus II menjadi 3,03 yang termasuk kategori baik. Dari pembahasan tersebut dapat diketahui bahwa penerapan model pembelajaran tipe TGT (Team Games Tournament) dapat meningkatkan motivasi dan hasil belajar siswa Kelas VIII G SMP Negeri 1 Nusawungu, dengan rincian motivasi siswa sebelum menggunakan model pembelajaran tipe TGT temasuk kategori cuku, setelah menggunakan pembelajaran tipe TGT mengalami peningkatan menjadi kategori baik, dan persentase ketuntasan dari 33,33\% menjadi 83,33\% . peningkatan yang terjadi tidak lepas dari peran guru dalam menerapkan suatu model pembelajaran, hal ini dapat dilihat pada aktivitas guru yang sebelumnya termasuk kategori cukup meningkat menjadi baik.

\section{KESIMPULAN}

Berdasarkan hasil penelitian dan analisis data yang telah dilakukan, maka peneliti membuat kesimpulan penerapan model pembelajaran tipe TGT (Team Games Tournament) dapat meningkatkan motivasi dan hasil belajar siswa kelas VIII G SMP Negeri 1 Nusawungu dengan melalui 2 (dua) siklus pembelajaran. Guru dapat menggunakan alternatif model pembelajaran tipe TGT sehingga dapat menambah variasi pembelajaran di kelas.

\section{SARAN}

Perlu dilakukan berbagai penelitian di semua mata pelajaran dengan menggunakan strategi TGT 


\section{DAFTAR PUSTAKA}

Anita Lie. 2008. Cooperative Learning: Mempraktikkan Cooperative Learning di RuangRuang Kelas. Jakarta: Grasindo.

B. Suryosubroto. 2002. Proses Belajar Mengajar di Sekolah. Jakarta: Rineka Cipta.

Basuki Wibawa. 2003. Penelitian Tindakan Kelas. Jakarta: Depdiknas.

Brian Clegg. 2001. Instant Motivation: 79 Cara Instan Menumbuhkan Motivasi. Jakarta: Erlangga.

Cece Wijaya. 2000. Kemampuan Dasar Guru dalam Proses Belajar Mengajar. Bandung: Remaja Rosdakarya.

Dimyati \& Mudjiono. 2002. Belajar dan Pembelajaran. Jakarta: Rineka Cipta.

E. Mulyasa. 2003. Kurikulum Berbasis Kompetensi: Konsep, Karakteristik, dan Implementasi. Bandung: Remaja Rosdakarya.

Etin Solihatin \& Raharjo. 2007. Cooperative Learning. Jakarta: Bumi Aksara.

Hamzah B. Uno. 2008. Teori Motivasi dan Pengukurannya Analisis di Bidang Pendidikan. Jakarta: Bumi Aksara.

Hisyam Zaini, Bermawy Munthe, Sekar Ayu Aryani. 2004. Strategi Pembelajaran Aktif. Yogyakarta: CTSD.

Kiranawati. 2007. Pembelajaran Kooperatif Tipe Teams Games Tournament (TGT).

http://gurupkn.wordpress.com/2007/11/13/metode-team-games- tournament-tgt/ (Diakses: 28 Agustus 2016).

Melvin L. Silberman. 2007. Active Learning: 101 Strategi Pembelajaran Aktif. Yogyakarta: Pustaka Insan Madani.

Moh. Uzer Usman. 2003. Upaya Optimalisasi Kegiatan Belajar Mengajar. Bandung: Remaja Rosdakarya.

Muflihah. 2004. Penerapan Pembelajaran Kooperatif Tipe TGT (Teams Games Tournament) dalam Meningkatkan Hasil Belajar Siswa pada Pokok Bahasan Persamaan Linier dengan Dua Peubah Kelas II SMP N II Surakarta. Skripsi: UMS.

Muslimin Ibrahim, Fida Rachmadiarti, Mohamad Nur \& Ismono. 2000. Pembelajaran Kooperatif. Surabaya: Pusat Sains dan Matematika UNESA.

Nana Sudjana. 2006. Penilaian Hasil Proses Belajar Mengajar. Bandung: Remaja Rosdakarya. 
Nasution. 2005. Berbagai Pendekatan dalam Proses Belajar Mengajar. Jakarta: Bumi Aksara.

Nurul Zuriah. 2006. Metodologi Penelitian Sosial dan Pendidikan Teori-Aplikasi. Jakarta: Bumi Aksara.

Oemar Hamalik. 1995. Metode Belajar dan Kesulitan-Kesulitan Belajar. Bandung: Remaja Rosdakarya. 